\title{
Effects of microbial and chemical fertilizers on vegetative and reproductive characteristics of brinjal (Solanum melongena linn.) Cv. Ndbh-1.
}

\author{
Ram Awadh Awasthi \\ Department of Horticulture, Kulbhasker Ashram Post Graduate College, Allahabad (U.P.) \\ Email:
}

\begin{abstract}
To study the influence of organic and inorganic on quality and yield components in brinjal to boost the productivity potential combined application of microbial and chemical fertilizers had a great influence at all the growth stages of the crop. Significant differences in all parameters like, plant height, number of leaves, leaf area and number of branches due to the combined application of microbial fertilizer and chemical fertilizer. Maximum plant height $(65.23 \mathrm{~cm})$ was observed in Treatment-5 containing NPK+ Phosphobacteria (each $7 \mathrm{~g} / \mathrm{pot}$ ). The maximum number of flowers (37.25) per plant was produced in $\mathrm{T} 5$ treatment and the maximum number of fruits (27.25/plant). The highest number of branches per plant (26.25) was recorded in treatment T5. Highest fruit weight was observed in T5 was (172.23g). Total number of leaf observed 185.33 per plant was observed in T-5, and leaf area fairly gives a good idea of photosynthetic capacity of the plant. Significant differences were noticed with regard to leaf area index among the treatments at all growth stages.
\end{abstract}

Key words: DAP, NPK, urea Azospirillum, Phosphobacteria, chemical fertilizer and egg plant.

Paper Cited: Awasthi, R.A. (2017). Effects of microbial and chemical fertilizers on vegetative and reproductive characteristics of brinjal (Solanum melongena linn.) Cv. Ndbh-1. South Asian Journal of Food Technology and Environment, 3(2): 576-580.

\section{Introduction}

Brinjal (Solanum melongena Linn.) is well responsive to nutrition and found to have great variability with varieties, climatic conditions and soil fertility. It is voracious feeder trait may be utilize to maximize productivity. It belongs to family Solanaceae. Plant is herbaceous, annual with erect or semispreading in habit. It also behaves like a herb. Brinjal is popular vegetable and native of India. It can be grown throughout the year in almost all the states of India except at higher altitudes. The important brinjal growing countries in the world are India, Bangladesh, Pakistan, China, Cyprus, Egypt, Japan,

The experiment was carried out in a Completely Randomized Block each unit Design (CRBD) at the Department of Horticulture, Kulbhasker Ashram Post Graduate College, Allahabad during the year 2014-15. The mechanical compositions, physical and chemical properties of experimental soil, which was used for pot culture study. The physical and
Philippines, Syria and Western Europe (Anon 2001). In India, major brinjal producing states are Orissa, Bihar, Karnataka,West Bengal, Andhra Pradesh, Maharashtra and Uttar Pradesh. The varieties of Solanum melongena L., show a wide range of fruit shapes and colors, ranging from oval or egg-shaped to long club shaped; and from white, yellow, green through degrees of purple pigmentation to almost black. It is quite high in nutritive value and can be well compared with tomato. Farmers may boost-up their socio-economic status by growing brinjal if assured and remunerative yield obtained from this crop.

\section{Materials and Methods}

chemical properties of soils such as $\mathrm{pH}$, Nitrogen (Jackson, 1958), Phosphorus (Jackson, 1958) and potassium (Peach and Tracey, 1956) contents were analyzed. The raised seed bed of $3.0 \times 1.5 \mathrm{~m}$ size was prepared, and Brinjal seeds were sown in one centimeter depth in the rows spaced at $7 \mathrm{~cm}$ and covered with thin layer of FYM. Seedlings of 25days were transplanted to 
the trial pot. The treatments were T-1 DAP+ Azospirillum (7g / pot),T-2 DAP+Phosphobacteria (7g / pot), T-3 DAP+Potassium mobilizer ( $7 \mathrm{~g} / \mathrm{pot}), \mathrm{T}-4$ NPK Mixture+Azospirillum (10g/pot), T-5 NPK mixture +Phosphobacteria (7g/pot), T-6 NPK mixture +Potassium mobilizer $(7 \mathrm{~g} /$ pot), T-7 Urea+ Azospirillum (each 7g/pot), T-8 Urea+ Phosphobacteria (each $7 \mathrm{~g} /$ pot), T-9 Urea+ Potassium mobilize ( $7 \mathrm{~g} / \mathrm{pot}), \mathrm{T}-10$ Urea ( Control, 7g/ pot). Five plants were selected randomly from plot to record yield contributing characters. All practical managements included; mulching, weeding and other agronomic treatments were done mechanically. Irrigation was done based onplant requirements. In maturity time, fruit yield, number of fruits per plant, total plant height, shoot length, root length, number of branches per plant, number of leaves and leaf area per plant, fruit length and fruit width were measured. The collected data were analyzed statistically by F-test to examine the treatment effects and the mean differences were adjudged by Duncan's Multiple Range Test (DMRT) (Gomez and Gomez, 1984).

\section{Results and Discussion}

The present study was observed that the application of microbial and chemical fertilizers combined application had a great influence at all the growth stages of the crop. Significant differences in all parameters like, plant height, number of leaves, leaf area and number of branches due to the combined application of microbial fertilizer and chemical fertilizer. Maximum plant height $(65.23 \mathrm{~cm})$ was observed in T5 (Table 1). The data on shoot length $(36.25 \mathrm{~cm})$, and root length $(51.25 \mathrm{~cm})$ as influenced by the combination of biofertilizers and chemical fertilizers showed significant differences among the treatments at all the stages. The highest number of branches per plant (26.25nos) was recorded in treatment T5. Highest fruit weight was observed in T5 (172.23g). Total number of leaf observed 185.33 per plant was observed in T-5, and leaf area fairly gives a good idea of photosynthetic capacity of the plant.

Significant differences were noticed with regard to leaf area index among the treatments at all growth stages. The treatment 5 showed significantly higher leaf area (1720.23 $\mathrm{cm}^{2}$ ). The increase in leaf area index could be attributed to increased cell division and elongation resulting in increased leaf expansion, more number of leaves due to beneficial influence of biofertilizers which release growth promoting substances and enhances the availability of nitrogen. From the data it appeared that flowering and fruiting of brinjal were positively influenced by sources of nutrients applied. The maximum number of flowers (37.25/plant) per plant was produced in T5 treatment and the maximum number of fruits (18.33/plant). Similar results were also reported by Naidu et al., (1999) revealed that the morphological parameters were affected significantly due to the application of different combination of organics, chemicals and biofertilizers.

Nitrogen fertilizer use has played a significant role in increase of crop yield (Modhej et al., 2008). Significant increase in plant height, number of leaves, number of branches and number of fruits due to influenced by environmental conditions and management practices. Prabhu et al., (2003) studied to indicate that plant height is increased by the application of organics and biofertilizers, attributed to the increased uptake of nutrients in the plants leading to enhanced chlorophyll content and carbohydrate synthesis and increased activity of hormones produced by Azospirillum and phosphate solubilizing bacteria. The Phosphobacteria increased phosphate availability in soils which in turn helped better proliferation of root growth and uptake of other nutrients to the greater extent. So that the enlargement in cell size and cell division, which might have helped in plant height, number of leaves, branches number of fruits per plant. These results are in agreement with those reports of Nanthakumar and Veeraraghavathatham (2000), Anburani and Manivannan (2002), and Wange and Kale (2004) in brinjal. Fundamentally, $\mathrm{K}^{+}$is very water soluble and highly mobile and transported in the plants xylem (Lack and Evans, 2005). Membrane transport of potassium can be mediates either by potassium channels, utilizing the membrane potential to facilitate transport of potassium down its electrochemical gradient,or by 

melongena linn.) Cv. Ndbh-1.

secondary transporters. In plants, potassium act as regulator since it is constituent of 60 different enzyme systems of drought tolerance and wateruse efficiency. In addition, current study has showed that to optimum growth, crops need more potassium than needed (Simonsson et al., 2007). Aminifard et al., (2010) with study responses of eggplant to different rates of nitrogen under field conditions were reported that fertilization with $100 \mathrm{Kg} / \mathrm{ha}$ nitrogen resulted in the highest average fruit weight and fruit yield. Pal et al., (2002) were reported that eggplant fruit yield increased with increase in nitrogen up to $187.5 \mathrm{~kg} / \mathrm{ha}$. Only microbial treated plants could not increase the vegetative growth of plants and the reason may be that they released nutrients at a slower rate. On the other hand, the only application of inorganic fertilizer was also less effective than the combined application. These results were inconformity with the findings of Rahman et al., (1998) found that the vegetative growth and yield of berry was the highest with the combined application of manures and fertilizers.

Table 1: The effect of microbial and chemical fertilizer on vegetative characteristics of brinjal plant. cv.NDBH-1.

\begin{tabular}{|c|c|c|c|c|c|c|c|}
\hline Treatments & $\begin{array}{c}\text { Plant } \\
\text { height(cm) }\end{array}$ & $\begin{array}{c}\text { Shoot } \\
\text { length } \\
(\mathbf{c m})\end{array}$ & $\begin{array}{c}\text { Shoot } \\
\text { /plant(no) }\end{array}$ & $\begin{array}{c}\text { Leaves/plant } \\
\text { (cm) }\end{array}$ & $\begin{array}{c}\text { Leaf } \\
\text { area/plant } \\
\text { (cm2) }\end{array}$ & $\begin{array}{c}\text { Root/plant } \\
\text { (no) }\end{array}$ & $\begin{array}{c}\text { Root } \\
\text { length } \\
\text { (cm) }\end{array}$ \\
\hline $\mathrm{T}_{1}$ & 50.11 & 20.01 & 12.21 & 120.12 & 1110.21 & 11.20 & 30.25 \\
\hline $\mathrm{T}_{2}$ & 52.33 & 22.41 & 14.24 & 142.01 & 1320.25 & 13.22 & 32.22 \\
\hline $\mathrm{T}_{3}$ & 51.12 & 21.01 & 13.21 & 130.11 & 1201.22 & 12.02 & 31.02 \\
\hline $\mathrm{T}_{4}$ & 62.21 & 32.01 & 23.10 & 162.21 & 1500.20 & 22.23 & 52.36 \\
\hline $\mathrm{T}_{5}$ & 65.23 & 36.25 & 26.25 & 185.33 & 1720.23 & 25.14 & 55.65 \\
\hline $\mathrm{T}_{6}$ & 61.51 & 33.41 & 24.00 & 154.00 & 1445.01 & 23.02 & 51.25 \\
\hline $\mathrm{T}_{7}$ & 45.44 & 30.00 & 9.25 & 95.33 & 950.23 & 8.35 & 35.36 \\
\hline $\mathrm{T}_{8}$ & 48.25 & 31.02 & 10.23 & 100.23 & 1000.25 & 9.36 & 38.44 \\
\hline $\mathrm{T}_{9}$ & 46.21 & 29.22 & 9.89 & 96.65 & 960.56 & 8.55 & 36.25 \\
\hline $\mathrm{T}_{10}$ & 36.23 & 15.64 & 5.54 & 55.65 & 565.85 & 4.56 & 25.68 \\
\hline $\mathrm{MSE}+$ & 8.25 & 4.22 & 2.14 & 12.02 & 45.36 & 1.20 & 3.36 \\
\hline
\end{tabular}

Table 2: The effect of microbial and chemical fertilizer on reproductive characteristics of brinjal plant. cv.NDBH-1.

\begin{tabular}{|c|c|c|c|c|c|c|c|}
\hline Treatments & $\begin{array}{c}\text { Anthesis } \\
\text { time } \\
\text { (DAP) }\end{array}$ & $\begin{array}{c}\text { Flower/ } \\
\text { plant } \\
\text { (no) }\end{array}$ & $\begin{array}{c}\text { Fruit } \\
\text { setting } \\
\text { /plant } \\
\text { (no) }\end{array}$ & $\begin{array}{c}\text { Fruit / } \\
\text { plant (kg) }\end{array}$ & $\begin{array}{c}\text { Single Fruit } \\
\text { weight (g) }\end{array}$ & $\begin{array}{c}\text { Fruit yield } \\
\text { /plant (kg) }\end{array}$ & $\begin{array}{c}\text { Fruit } \\
\text { yield } \\
\text { (Q/ha) }\end{array}$ \\
\hline $\mathrm{T}_{1}$ & 70.11 & 21.01 & 13.21 & 10.12 & 111.21 & 1.100 & 330.25 \\
\hline $\mathrm{T}_{2}$ & 72.33 & 23.41 & 15.24 & 142.01 & 132.25 & 1.320 & 332.22 \\
\hline $\mathrm{T}_{3}$ & 71.12 & 22.01 & 14.21 & 13.11 & 120.22 & 1.200 & 331.02 \\
\hline $\mathrm{T}_{4}$ & 66.21 & 33.01 & 24.10 & 16.21 & 150.20 & 2.230 & 552.36 \\
\hline $\mathrm{T}_{5}$ & 65.23 & 37.25 & 27.25 & 18.33 & 172.23 & 2.540 & 555.65 \\
\hline $\mathrm{T}_{6}$ & 66.51 & 34.41 & 25.00 & 15.00 & 144.01 & 2.320 & 551.25 \\
\hline $\mathrm{T}_{7}$ & 75.44 & 31.00 & 10.25 & 9.33 & 95.23 & 0.830 & 335.36 \\
\hline $\mathrm{T}_{8}$ & 78.25 & 32.02 & 11.23 & 10.23 & 100.25 & 0.930 & 338.44 \\
\hline $\mathrm{T}_{9}$ & 76.21 & 30.22 & 10.89 & 9.65 & 96.56 & 0.850 & 336.25 \\
\hline $\mathrm{T}_{10}$ & 96.23 & 16.64 & 6.54 & 5.65 & 56.85 & 0.456 & 225.68 \\
\hline $\mathrm{MSE}_{-}$ & 9.25 & 5.22 & 3.14 & 1.02 & 4.36 & 0.120 & 33.36 \\
\hline
\end{tabular}


For eggplant, the integrated use of urea and poultry manure also resulted in a higher nutrient uptake. The use of synthetic fertilizers causes a great impact on the environment and the cost of these fertilizers is increasing over the years. The farmers need to raise the crops by organic farming that will reduce the costs and will decrease the impact on the environment. In addition, organic farming will reduce the additional burden of environmental pollution that is caused while manufacturing these synthetic fertilizers at the source (Rathier and Frink, 1989). Now it is a well established fact that organic fertilizers provide enough requirements for proper growth of the crop plant and may enhance the uptake of nutrients, increase the assimilation capacity and will stimulate the hormonal activity as well (Tomati et al., 1990). The use of biofertilizers useful as it increases soil porosity, aeration and water holding capacity, therefore a practically paying proposal. Azospirillum, a nitrogen fixing organism has been reported to be beneficial and economical on several crops. They improve the growth and yield as well as productivity of the crop. Vanangamudi et al., (1989) also reported similar increase in per cent germination and shoot length of chilli with increase in nitrogen application (0 $150 \mathrm{~kg} / \mathrm{ha})$. Prabhu et al., (2003) reported that increased $\mathrm{N}$ and $\mathrm{P}$ rates increased the plant height, branch number per plant in brinjal phosphate solubilizing Bacteria (PSB) are a group of beneficial bacteria capable of hydrolysing organic and inorganic phosphorus from insoluble compounds.

P-solubilization ability of the microorganisms is considered to be one of the most important traits associated with plant phosphate nutrition. P-solubilizers are biofertilizers which solubilizes the fixed phosphorus in soil and makes it available for plants (Chen et al., 2006). The microbes, Fraturia aurantia belonging to the family Pseudomonaceae, is a beneficial bacteria capable of mobilizing potash to plants in all types of soil especially, low K Content soil. Such bacterial population in the soil form can increase the availability of potash to the plants. Wange and Kale (2004) reported that the significant improvement in vegetative characters such as plant height and number of leaves per plant in brinjal over the recommended biofertilizer with combine chemical fertilizer. The information on the role of organics on morphophysiological traits in brinjal is meager. Hence, there is a need to study the influence of organic and inorganic on quality and yield components in brinjal to boost the productivity potential.

\section{Conclusion}

The cost of inorganic fertilizers has been enormously increasing to an extent that they are out of reach of the poor, small and marginal farmers. It has become impractical to apply such costly inputs for a crop of marginal returns. The use of biofertilizers in such situation is therefore a practically paying proposal. Based on the above results, it was concluded that, the application of microbial and chemical fertilizers was found more beneficial and significantly improved morpho-physiological traits, growth parameters, and yield components in brinjal. The benefit cost ratio was found lesser in using both biofertilizer and chemical fertilizer compared to using chemical fertilizer alone in brinjal crop cultivation.

\section{References}

1. Aminifard, M.H., Aroiee, H., Fatemi, H., Ameri, A. and Karimpour, S. (2010). Responses of Eggplant (Solanum Melongenal L.) to different rates of nitrogen under field conditions. JCEA, 11(4): 453-458.

2. Anburani, A. and Manivannan, K. (2002). Effect of integrated nutrient management on growth in brinjal (Solanum melongena L.) CV. Annamalai. South Indian Horticulture, 50(4-6): 377-386.

3. Anon. (2004). Report of the Ad Hoc technical Expert Group on Forest Biological Diversity. (UNEP/CBD/SBSTTA/7/6). Anonymous, Food and Agriculture Organization, Production Year book, 54: 148-149.

4. Chen, G.C., He, Z.L, Stoffella, P.J, Yang, X.E. and Yu, S. (2006). Calvert D, Use of dolomite phosphate rock (DPR) fertilizers to reduce phosphorus leaching from sandy soil. Environmental Pollution, 139: 176182. 

melongena linn.) Cv. Ndbh-1.

5. Gomez, K.A. and Gomez, A.K. (1958). Statistical Procedures for Agricultural Research. $2^{\text {nd }}$ edn. John Wiley and Sons. New York. 207-215.

6. Jackson, M.L. (1958). Soil Chemical Analysis. Englewood Cliff, N.J.: Prentice Hall, Inc., 183-204.

7. Lack, A.J. and Evans, D.E. (2001). Instant notes in plant biology, $1^{\text {st }}$ edn. Oxford: Bios Scientific Publishers.

8. Modhej, A., Naderi, A., Emam, Y., Aynehband, A. and Normohamadi, G.H. (2008). Effects of post-anthesis heat stress and nitrogen levels on grain yield in wheat (T. durum and $T$. aestivum) genotypes. International Journal of Plant Production, 2: 257-267.

9. Naidu, A.K., Kushwah, S.S. and Dwivedi, Y.C. (1999). Performance of organic manures, bio and chemical fertilizers and their combinations on microbial population of soil and growth of okra. Jawaharalal Neharu Krishi Vishwa Vidhyalaya Research Journal, 33 (1-2): 34-38.

10. Nanthakumar, S. and Veeraraghavathatham, D. (2000). Effect of integrated nutrient management on growth parameters and yield of brinjal (Solanum melongena L.) cv. PLR-1. South Indian Horticulture, 48(1-6): 31-35.

11. Pal, S., Saimbhi, M.S. and Bal, S.S. (2002). Effect of nitrogen and phosphorus levels on growth and yield of brinjal hybrid (Solanum melongena L.). Journal of Vegetable Science. 29: 90-91.

12. Peach, K. and Tracey, M.V. (1956). Modern Methods of Plant Analysis. Vol. I, Springer Verlag, Berlin.
13. Prabhu, M., Veeraraghavathatham, D. and Srinivasan, K. (2003). Effect of nitrogen and phosphorus on growth and yield of brinjal hybrid COBH-1. South Indian Horticulture, 51(1-6): 152-156.

14. Rahman, M.H., Hossain, M.A., Kawai, K. and Hossain, M.A. (1998). Potentiality of swamp for fish culture in Bangladesh. Japan Aquaculture Society, Svisanzoshku, 46 (4):481-486.

15. Rathier, T.M. and Frink, C.R. (1989). Nitrate in runoff water from container grown juniper and alberta spruce under different irrigation and $\mathrm{N}$ fertilization regimes. Journal of Environmental Horticulture, 7(1): 3235.

16. Simonsson, M., Andersson, S., AndristRangel, Y., Hillier, S., Mattsson, L. and Obom, I. (2007). Potassium release and fixation as a function of fertilizer application rate and soil parent material. Geoderma- Journal, 140:188-198.

17. Tomati , U., Galli, E., Grappelli, A. and DiLena, G. (1990). Effect of earthworm casts on protein synthesis in radish (Raphanus sativum) and lettuce (Lactuca sativa) seedlings. Biology and Fertility of Soils, 9: 288289.

18. Vanangamudi, K., Subramanian, K.S. and Bhaskaran, M. (1989). Irrigation and nitrogen management for quality seed production. Seeds and Farms 15 (9-10): 28-31.

19. Wange, S.S. and Kale, R.H. (2004). Effect of biofrtilizers under graded nitrogen levels on brinjal crop. Journal of Soils and Crops, 14(1): 9-11.

\begin{tabular}{|ll|}
\hline Received & : July, 2017 \\
Revised & : Oct., 2017 \\
Published & : Dec., 2017 \\
\hline
\end{tabular}

